\title{
55
}

\section{EKSISTENSI PEKERJA SOSIAL DI RANAH INDUSTRI INDONESIA}

\author{
Oleh : \\ Danny Dwi Septianto, Sri Sulastri, Gigin Ginanjar Kamil Basar
}

\begin{abstract}
ABSTRAK
Setiap pekerja industri di seluruh dunia pasti memiliki resiko kecelakaan yang besar khususnya di Indonesia, hal tersebut tentu membuat perasaan cemas ke para pekerja di perusahaan tersebut belum lagi resiko kehilangan pekerjaan yang bukan karena kinerja mereka buruk atau kesalahan kerja, melainkan karena adanya pergantian pekerja dari manusia ke mesin hal itu tentu member rasa cemas yang bertambah besar dan belum lagi masalah sosial kronis seperti alienation,alcoholism,absenteeism,accidents dan abuse yang masih menyelimuti banyak pekerja yang bekerja di ranah industrialisasi. Dan di Indonesia masih belum ada indikasi bahwa Indonesia akan lebih memperhatikan dan mensejahterakan para pekerja dan lebih memanusiawi kan pekerja di ranah industrialisasi khususnya kepada pekerja yang tidak memiliki jabatan yang tinggi. Mungkin karena para pekerja tersebut dianggap tidak berpengaruh atau memang belum ada atau sengaja tidak mengadakan program pelayanan sosial bagi pegawai, yang jelas adalah Indonesia kini butuh pekerja sosial industri untuk memperhatikan pekerja, memberi rasa aman bagi para pekerja dan memberi rasa aman kepada keluarga yang ditinggalkan pekerja baik itu untuk keluar kota karena pekerjaan atau meninggal dunia. Serta dengan metode yang dimiliki pekerja sosial khususnya pekerja sosial industri maka masalah sosial kronis yang diderita oleh pekerja yang bekerja di ranah industrialisasi dapat ditangani agar pekerja dapat melakukan fungsi sosialnya dengan baik dan member dampak positif pada perusahaan. Hal tersebut yang harus di perhatikan oleh perusahaan-perusahaan Indonesia saat ini mengingat industrialisasi merupakan salah satu faktor prnting pembangunan sebuah negara.
\end{abstract}

Keyword: Industri, Pekerja Sosial, Pekerja Sosial Industri

\section{Pendahuluan}

Sadarkah anda sekarang bahwa segala sesuatu yang ada disekeliling anda seperti yang anda lihat, anda rasakan, anda kenakan, anda makan sampai yang anda gunakan untuk tidur nanti sampai bangun kembali, semua adalah hasil dari kegiatan industri. Secara sadar atau tidak sadar anda sudah mengeluarkan banyak atau sedikit uang untuk perusahaan industri tersebut, anda telah memberikan keuntungan bagi perusahaan tersebut anda juga telah menggaji semua karyawan perusahaan terkait. Tapi tahukah anda apa yang sebenarnya terjadi, masalah dan resiko apa yang terdapat didalam kegiatan industri khususnya di negara kita Indonesia, yang kita tahu sebagian besar orang menganggap segala sesuatunya tidak berjalan dengan semestinya? Dan apakah perusahaan di Indonesia memiliki sesuatu untuk diberikan kepada pegawainya agar selalu merasa aman dan nyaman ketika bekerja begitu pula tanpa memikirkan keluarga mereka ketika bekerja?

Indonesia merupakan sebuah negara yang memiliki kekayaan alam yang melimpah namun masih belum sejahtera sampai saat ini, banyak sekali kekayaan alam Indonesia yang terkuras habis namun tidak memberikan efek positif kepada masyarakat Indonesia sendiri, hal itu dikarenakan 
sumber daya alam yang ada di Indonesia lebih banyak dimanfaatkan oleh perusahaan-perusahaan dari negara luar dan hanya sedikit sekali masyarakat Indonesia yang terkena efek positif dari keberadaan perusahaan-perusahaan asing tersebut. Selain itu kondisi pekerja Indonesia khususnya di ranah industri sangat memprihatinkan baik itu pegawai yang memiliki jabatan atau buruh. Berbicara tentang industri khususnya kepada pegawai dan buruh, Indonesia merupakan negara yang belum sepenuhnya memperhatikan kesejahteraan pegawainya, padahal kesejahteraan pegawai sangat penting untuk kondisi perusahaan. Bila pegawai didalam kondisi yang sedang menurun diakibatkan adanya masalah pribadi baik dari keluarga atau lingkungan kerja maka dikhawatirkan pegawai tersebut bekerja tidak maksimal dan menimbulkan dampak negatif terhadap perusahaan, begitu juga dengan kondisi buruh di Indonesia, kesehatan tempat kerja seakan tidak menjadi urusan pihak perusahaan dan hal itu juga tidak diseimbangkan dengan upah yang diberikan perusahaan terhadap buruh, hal itu juga dikhawatirkan dapat memberi dampak negatif terhadap perusahaan. Kita dapat mengetahui bahwa ranah industri merupakan salah satu kekuatan untuk pembangunan ekonomi sebuah negara dan kesejahteraan rakyatnya.

\section{ISU DAN MASALAH PEGAWAI}

Kita dapat mengetahui orang yang bekerja di ranah industri tidak dihadapkan pada "pekerjaan rumah" perusahaan saja, mereka harus berjibaku dengan dunia luar perusahaan seperti kemungkinan timbul masalah keluarga, kemacetan di jalan, kebutuhan yang belum tercukupi sampai dengan isu pemecatan atau sistem outsourcing yang tidak memberi kepastian kepada pegawai dan memberikan kecemasan setiap waktunya. Dan khusus di Indonesia masalah juga semakin diperparah dengan kurang berlaku sampai tidak adanya jaminan untuk pegawai khususnya buruh dan pegawai dengan jabatan rendah.

Pekerjaan,seperti kata Smith (1988), merupakan salah satu dimensi yang paling penting dalam kehidupan seorang individu. Dalam beberapa aspek,setiap individu memaknakan dirinya dalam kaitanya dengan apa yang dia lakukan melalui pekerjaanya. Mengutip Perlman, Smith menambahkan bahwa pekerjaan memberikan seseorang sebuah identitas sosial-yakni sebuah pijakan bagi masyarakat yang lebih luas serta sebuah medium dengan mana nilai dan kedudukan seseorang dalam masyarakat diketahui oleh orang lain (Smith, 1988:3). Namun demikian, perubahan sosial kadangkala tidak selalu ramah terhadap manusia. Industrialisasi, misalnya, adalah salah satu proses perubahan sosial yang sangat berpengaruh terhadap pekerjaan manusia.

Masalah yang sekarang dikhawatirkan para pegawai khususnya di Indonesia adalah mekanisasi dan otomatisasi yang merupakan fenomena industrialisasi yang melahirkan rutinitas dan membuat tenaga manusia tampak semakin tidak penting. Para pegawai kerah biru maupun putih merasa tidak bermakna dan terancam kapan saja dapat digantikan oleh sainganya, mesin. Perubahan tekhnologi, pergantian tenaga kerja (shift), dan pemutusan hubungan kerja yang semakin menjadi fenomena sehari-hari pada masyarakat industri, sering menimbulkan kecemasan bagi para pegawai. Mengutip Edi Suharto (2005), beliau mengatakan bahwa, di Amerika Serikat proses otomatisasi menggantikan sekitar dua juta pekerjaan setiap tahunya (Suharto, 2005:15). Para pegawai yang merasa tidak berguna dan tidak berdaya dalam pekerjaannya seringkali membawa permasalahan tersebut ke rumah dan lingkungan masyarakat. Hal ini merupakan sebuah ancaman yang dianggap menakutkan bagi para pegawai perusahaan dan perasaan terlupakan tersebut harus segara dilupakan untuk menunjang kestabilan kerja mereka dan memberikan profit yang sebesar-besarnya bagi perusahaan.

Ada beberapa permasalah sosial kronis yang memang sering sekali terjadi di dalam dunia industri yang menghampiri individu/pegawai. Dan masalah yang terkait dengan dampak negatif industrialisasi yang oleh Johnson disingkat menjadi 5A (dalam Suharto,2005: 16). 
- Alienation: perasaan keterasingan dari diri ,keluarga, dan kelompok sosial yang dapat menimbulkan apatis, marah dan kecemasan

- Alcoholism atau addiction:ketergantungan terhadap alcohol,obat-obatan terlarang atau rokok yang dapat menurunkan produktivitas, merusak kesehatan fisik dan psikis, dan kehidupan sosial seseorang

- Absenteeism: kemangkiran kerja atau perilaku membolos kerja dikarenakan rendahnya motivasi pegawai, perasaan-perasaan malas, tidak berguna, tidak merasa memiliki perusahaan, atau sakit fisik dan psikis.

- Accidents:kecelakaan kerja yang diakibatkan oleh penurunan konsentrasi pegawai atau oleh lemahnya sistem keselamatan dan kesehatan lingkungan kerja

- Abuse: bentuk-bentuk perlakukan salah terhadap anak-anak atau pasangan dalam keluarga (suami terhadap istri atau sebaliknya), seperti memukuldan menghardik secara berlebihan yang ditimbulkan oleh frustrasi, kebosanan, dan kelelahan di tempat kerjanya.

Beberapa permasalahan sosial lainya yang sering ditangani pekerja sosial adalah: diskriminasi di tempat kerja atau tindakan-tindakan tidak adil terhadap wanita, kaum minoritas, imigran, remaja, pensiunan dan para penyandang cacat. Beberapa industri dan perusahaan juga kerap menimbulkan dampak negatif terhadap masyarakat di sekitarnya, seperti polusi (udara, air, suara) dan kerusakan fisik dan psikis bagi para pegawai.

Pekerja sosial dapat membantu dunia industri untuk mengidentifikasi dan mengatasi berbagai biaya sosial (social costs) yang ditimbulkan oleh perusahaan. Namun apakah industrialisasi di Indonesia sudah memiliki divisi atau bahkan lembaga untuk pelayanan pegawainya? Hal itu sangat ironis jika kita mengetahui bahwa di Indonesia pekerja sosial industri belum banyak dikenal di dunia kerja Indonesia serta belum banyak memiliki pekerja sosial di dalam industrialisasi dan masih kurangnya perhatian kepada program pelayanan pegawai sehingga wajar saja jika para pekerja di Indonesia belum memiliki rasa aman dan nyaman akan pekerjaanya karena belum memiliki jaminan di tempat kerjanya.

\section{PERAN PEKERJA SOSIAL}

Pekerjaan sosial adalah suatu bidang keahlian yang mempunyai tanggung jawab untuk memperbaiki dan atau mengembangkan interaksi diantara orang dengan lingkungan sosial sehingga orang ini memiliki kemampuan untuk menyelesaikan tugas-tugas kehidupan mereka, mengatasi kesulitan-kesulitan,serta mewujudkan aspirasi-aspirasi dan nilai-nilai mereka. Atas dasar pengertian ini, Soetarso mengatakan pekerjaan sosial memiliki tujuan, fungsi dan tugas-tugas sebagai berikut (Soetarso, 1995):

1. Meningkatkan kemampuan orang untuk menghadapi tugas-tugas kehidupan dan kemampuan untuk memecahkan masalah-masalah yang dihadapinya.

2. Mengkaitkan orang dengan sistem yang dapat menyediakan sumber-sumber, pelayananpelayanan, dan kesempatan-kesempat anyang dibutuhkannya.

3. Meningkatkan kemampuan pelaksanaan sistem tersebut secara efektif

4. Memberikan sumbangan bagi perubahan, perbaikan dan perkembangan kebijakan serta perundang-undangan sosial (1995:5)

Serta terdapat pula fungsi praktek pekerjaan sosial dan tugas -tugas pekerja sosial yaitu:

1. Membantu orang untuk meningkatkan dan menggunakan secara lebih efektif kemampuan mereka untuk melaksanakan tugas-tugas kehidupan mereka dan memecahkan masakah mereka

2. Menciptakan jalur hubungan pendahuluan dianara orang dengan sistem suber

3. Mempermudah interaksi,merubah dan menciptakan hubungan baru diantara orang dengan sistem sumber kemasyarakatan 
4. Mempermudah interaksi, merubah dan menciptakan hubungan diantara orang-orang dilingkungan sistem sumber

5. Memberikan sumbangan bagi perubahan, perbaikan dan perkembangan kebijaksanaan dan perundang-undangan sosial

6. Meratakan sumber-sumber material

7. Bertindak sebagai pelaksana control sosial (1995:5)

Tugas-tugas pekerja sosial yaitu :

1. Pekerja sosial menentukan dan mengadakan hubungan dengan orang yang membutuhkan guna penyelesaian tugas kehidupannya

2. Pekerja sosial dapat memberikan pengertian, dukungan, dan dorongan kepada orang-orang yang mengalami kritis seperti seseorang yang kehilangan pekerjaanya dan lain-lain

3. Pekerja sosial dapat memberikan kesempatan kepada orang untuk mengutarakan kesulitankesulitan mereka

4. Pekerja sosial dapat membantu orang untuk meneliti berbagai pilihan tentang cara menangani masalah dan cara menaggulangi masalah

5. Pekerja sosial dapat mengkonfrontasikanorang dengan realitas situasi yang nereka hadapi dengan jalan memberikan keterangan yang dapat mengganggu keseimbangan pribadi seseorang untuk kemudian diberikan motivasi guna terjadinya perubahan tertentu

6. Pekerja sosial dapat mengajarkan keterampilan kepada orang untuk mewujudkan aspirasi mereka. (1995:7)

Jika melihat dari seluruh peran yang dimiliki pekerja sosial rasanya Indonesia sangat membutuhkan peran dari pekerja sosial tersebut khususnya di bidang industri karena lingkungan industrilaisasi merupakan sebuah wilayah dimana banyak sekali masalah-maslah terjadi baik itu masalah kelompok atau individu, baik itu masalah di perusahaan sampai masalah keluarga di rumah, namun Indonesia masih belum peka bahwa sebenarnya pekerja sosial-lah yang dibutuhkan dalam kehidupan masyarakat industri karena tidak jarang timbulnya sebuah konflik dan penurunan kinerja akibat masalah-masalah yang ditimbulkan.

Profesi pekerja sosial sebenarnya juga sudah lama masuk ke ranah industrialisasi namun hanya di Indonesia yang memang belum banyak mengetahui tentang pekerja sosial industri, padahal bila ditelaah kehadiran pekerja sosial industri amat sangat membantu pegawai untuk memecahkan masalah atau hanya sekedar memotivasi pegawai agar kinerja mereka semakin baik dan memberikan profit yang besar bagi perusahaan.

\section{PEKERJA SOSIAL INDUSTRI}

Masyarakat berkembang kompleks. Sasaran, bidang garapan dan intervensi pekerjaan sosial juga semakin luas. Globalisasi dan industrialisasi telah membuka kesempatan bagi pekerja sosial untuk terlibat dalam bidang yang relative baru, yakni dunia industri. Dunia industri kini sedang menggali manfaat positif dari adanya kehadiran Pekerja Sosial Industri (PSI), baik terhadap aspek financial maupun relasi sosial dengan para pekerja dan masyarakat. Menurut Johnson (1984) di Amerika Serikat, sekitar setengah dari perusahaan terbesar kini memiliki apa yang dinamakan employee assistance programs (EAPs), program bantuan kesejahteraan sosial bagi para pekerja dan keluarganya. Dalam upaya kemangkiran kerja saja, perusahaan sanggu mengeluarkan biaya-biaya tambahan untuk program-program sosial dan penanggualngan alkoholisme (dalam Suharto, 2005). Pelayanan sosial seperti ini seringkali disebut sebagai "kontrak kemanusiaan" oleh karena itu dapat dikatakan bahwa misi utama PSI adalah lebih memanusiawikan dunia kerja.

Istilah "pekerjaan sosial industri“" sesungguhnya memiliki beberapa nama lain, misalnya pekerjaan sosial kepegawaian (occupational social worker), pekerjaan sosial di tempat kerja atau 
bantuan pelayanan bagi pegawai yang secara konsep PSI lebih luas dari konsep tanggung jawab sosial perusahaan (CSR) maupun pengembangan masyarakat (comdev). PSI mencakup pelayanan sosial yang bersifat internal dan eksternal. Secara internal, PSI melibatkan program-program bantuan bagi pegawai, seperti pelayanan konseling, terapi kelompok, dan pengembangan sumber daya manusia. Secara eksternal, PSI berwujud dalam berbagai bentuk program CSR termasuk di dalamnya strategi dan program pengembangan masyarakat (dalam Suharto, 2005:3).

Definisi dari pekerjaan sosial industri sendiri adalah sebagai lapangan praktik pekerjaan sosial yang secara khusus menangani kebutuhan-kebutuhan kemanusiaan dan sosial di dunia kerja melalui berbagai intervensi dan penerapan metoda pertolongan yang bertujuan untuk memelihara adaptasi optimal antara individu dengan lingkunganya, terutama di lingkungan kerja (Suharto, 2005:3). Dalam konteks ini, PSI dapat menangani beragam kebutuhan individu dan keluarga, rekasi dalam perusahaan, serta relasi yang lebih luas antara tempat kerja dan masyarakat yang dikenal dengan istilah tanggung jawab sosial perusahaan (corporate social responsibility)

\section{Tugas Pekerja Sosial Industri}

Menurut Johnson (1984:263-264) ada tiga bidang tugas pekerja sosial yang bekerja di perusahaan:

1. Kebijakan, perencanaan dan administrasi. Bidang ini umumnya tidak melibatkan pelayanan sosial secara langsung. Sebagai contoh, perumusan kebijakan untuk peningkatan karir, pengadministrasian program-program tindakan afirmatif. pengkoordinasian programprogram jaminan sosial dan bantuan sosial bagi para pekerja, atau perencanaan kegiatankegiatan sosial dalam departemen-departemen perusahaan.

2. Praktik langsung dengan individu, keluarga dan populasi khusus. Tugas pekerja sosial dalam bidang ini meliputi intervensi krisis (crisis intervention), asesmen (penggalian) masalahmasalah personal dan pelayanan rujukan, pemberian konseling bagi pecandu alkohol dan obatobatan terlarang, pelayanan dan perawatan sosial bagi anak-anak pekerja dalam perusahaan atau organisasi serikat kerja, dan pemberian konseling bagi para pensiunan atau pekerja yang menjelang pensiun.

3. Praktik yang mengkombinasikan pelayanan sosial langsung dan perumusan kebijakan sosial bagi perusahaan.

Para pekerja sosial telah memberikan kontribusi penting dalam memanusiawikan dunia kerja. Mereka umumnya terlibat dalam pemberian konseling di dalam maupun di luar perusahaan, pengorganisasian program-program personal, konsultasi dengan manajemen dan serikat-serikat kerja mengenai konsekuensi kebijakan-kebijakan perusahaan terhadap pekerja, serta bekerja dengan bagian kesehatan dan kepegawaian untuk meningkatkan kondisi lingkungan kerja dan kualitas tenaga kerja (dalam Suharto, 1997).

Menurut Straussner ada atu cara lagi untuk mengkonseptualisasikan beragam pelayanan sosial yang diberikan pekerja sosial beserta peranan dan keterampilan yang dijalankanya adalah dengan membuat sebuah tipologi model setting PSI (Straussner, dalam Suharto, 2005: 17), yaitu:

1. Model pelayanan sosial bagi pegawai

2. Model pelayanan sosial bagi majikan atau organisasi perusahaan

3. Model pelayanan sosial bagi konsumen

4. Model tanggung jawab sosial bagi perusahaan

5. Model kebijakan di bidang kepegawaian

Konsep yang di paparkan Straussner diatas semakin menguatkan indikasi bahwa pekerja sosial industri memiliki peran yang penting dalam sebuah perusahaan, karena dari pemaparan Straussner tersebut secara detail dan sistematis pelayanan apa saja yang dapat diberikan oleh pekerja sosial 
industri terhadap pegawai/pekerja dalam suatu perusahaan yang memiliki masalah sosial yang dapat mengganggu pekerjaan pegawai tersebut.

Dunia industri kini sedang menggali manfaat-manfaat positif dari adanya pelayanan sosial tersebut, baik tehadap aspek finansial maupun relasi sosial dengan para pekerja dan masyarakat. Di Amerika Serikat, sekitar setengah dari perusahaan-perusahaan terbesar kini memiliki apa yang dinamakan Employee Assistance Programs (EAPs), program-program bantuan kesejahteraan sosial bagi para pekerja dan keluarganya. Dalam upaya menurunkan tingkat kemangkiran kerja saja, peusahaan-perusahaan sanggup mengeluarkan biaya-biaya tambahan untuk program-program sosial dan penanggulangan alkoholisme. Pelayanan sosial seperti ini seringkali disebut sebagai "kontrak kemanusiaan" (human contract) atau "wajah manusiawi industri" (the human face of industry) (Suharto, 2006: 32)

\section{Penutup}

Indonesia pengetahuan tentang PSI ini masih amat sangat kurang padahal kita tahu bahwa bila kita mengevaluasi kegiatan dan program yang dimiliki oleh pekerja sosial industi pasti kita akan memberikan sebuah argumen bahwa yang sangat dibutuhkan oleh para pekerja di Indonesia adalah pekerja sosial industri, karena mayoritas pekerja di Indonesia masih belum mencapai kata sejahtera, masih ada pekerja/pegawai yang dilanda kecemasan berlebih dan terlebih jika memiliki masalah keluarga itu akan membuat pekerja tidak bekerja secara maksimal dan memiliki tingkat stress yang sangat tinggi dan memberikan dampak yang negatif terhadap perusahaan.

\section{Rekomendasi}

Seharusnya perusahaan-perusahaan di Indonesia lebih memperhatikan pekerja yang bekerja di perusahaan mereka, karena hal itu merupakan sebuah tanggung jawab dan merupakan sebuah aspek yang mempengaruhi perusahaan mereka karena kondisi pegawai mempengaruhi cara kerja mereka dan hal itu penting untuk kelangsungan perusahaan.

\section{DAFTAR PUSTAKA}

Suharto,Edi.2005.Pekerjaan Sosial di Dunia Industri Memperkuat CSR (Corporate Social Responsibility).

Soetarso (1995). Praktek Pekerjaan Sosial: Koperasi Mahasiswa STKS, Bandung: LSP STKS

Suharto, Edi (1997). Pembangunan, Kebijakan Sosial, dan Pekerjaan Sosial: Spektrum Pemikiran, Bandung: LSP STKS 